\author{
Jozef KRAJŇÁK ${ }^{1}$, Peter KAŠŠAY², Matej URBANSKÝ ${ }^{3}$ \\ Opiekun naukowy: Robert GREGA ${ }^{4}$ \\ DOI: https://doi.org/10.53052/9788366249837.14
}

\title{
BADANIE ELEMENTU SPRĘŻYSTEGO POD KĄTEM SIL POTRZEBNYCH DO JEGO ŚCIŚNIĘCIA
}

\begin{abstract}
Streszczenie: Artykuł opisuje elementy elastyczne stosowane w pneumatycznych sprzęgłach. Przedstawiono w nim wyniki badań dotyczących określenia niezbędnej siły wymaganej do ściśnięcia i rozciągnięcia elementów sprężystych w pneumatycznych sprzęgłach. Jako wynik badań wyznaczono energię niezbędną do odkształcenia elementów elastycznych stosowanych w pneumatycznych sprzęgłach.
\end{abstract}

Słowa kluczowe: siła, odkształcenie, ściskanie, rozciąganie, pneumatyczne sprzęgło, ciśnienie robocze.

\section{INVESTIGATION OF THE ELASTIC ELEMENT WITH REGARD TO THE FORCES REQUIRED FOR ITS COMPRESSION}

Summary: The presented article describes the elastic elements, which are used in the flexible pneumatic shaft couplings. It investigates the forces required for compression and expansion of these flexible elements. This article also analyses and evaluates deformation energy required to change volume of the flexible elements that are installed in the flexible pneumatic shaft couplings.

Keywords: force, deformation, compression, pneumatic element, shaft coupling, working pressure.

\section{Introduction}

The basic functional parts of the machine drives are: engine, coupling and gearbox. Our research team have been dealing with the shaft couplings for a long time. The shaft coupling is loaded due to acting of operational torque. The flexible shaft

${ }^{1}$ Technical University of Kosice, Faculty of Mechanical Engineering, jozef.krajnak@tuke.sk

${ }^{2}$ Technical University of Kosice, Faculty of Mechanical Engineering, peter.kassay@tuke.sk

${ }^{3}$ Technical University of Kosice, Faculty of Mechanical Engineering, matej.urbansky@tuke.sk

${ }^{4}$ Technical University of Kosice, Faculty of Mechanical Engineering, robert.grega@tuke.sk 
couplings are very often used kind of the shaft couplings. They have some relevant advantages compared to the conventional fixed couplings. [ 1, 2, 3, 5].

At our workplace, our research team is dealing with the matters concerning the flexible pneumatic couplings and their torsional loading. There are commonly used in these couplings the pneumatic spring elements, which are compressed and expanded during their operation. This process enables transmission of the working torque. $[8,9$, $10,12,13,15]$.

By changing the pressure of gaseous medium in the flexible element it is possible to tune the torsionally oscillating system and also to adjust its stiffness, damping or mass parameters according to the operational characteristics. Thanks to these adjustments it is ensured that during operation of the given technical system there are not occurring dangerous resonances, which are able to cause a damage of the whole technological equipment or to cause operator injury. At present, the main attention is paid to development and research of the pneumatic flexible members, which are formed from a rubber-cord casing filled with a gaseous medium. [4, 6, 11]. These elastic elements are dynamically stressed. However, it should be noted that the operational loading is not transmitted by the rubber, but it is transmitted by the gaseous medium with which the pneumatic coupling is filled. [ 7, 14].

The main task of this article is to determine the values of forces required for compression or expansion of the flexible pneumatic element. This flexible pneumatic element is an essential part of the flexible pneumatic shaft coupling.

\section{Pneumatic flexible elements}

The flexible pneumatic elements are used in various pneumatic devices. There are known many manufacturers of the flexible elements in the world. Different sizes and different numbers of bellows are also manufactured. Mostly there are produced the single-wave, double-wave and triple-wave elements, Fig. 1.

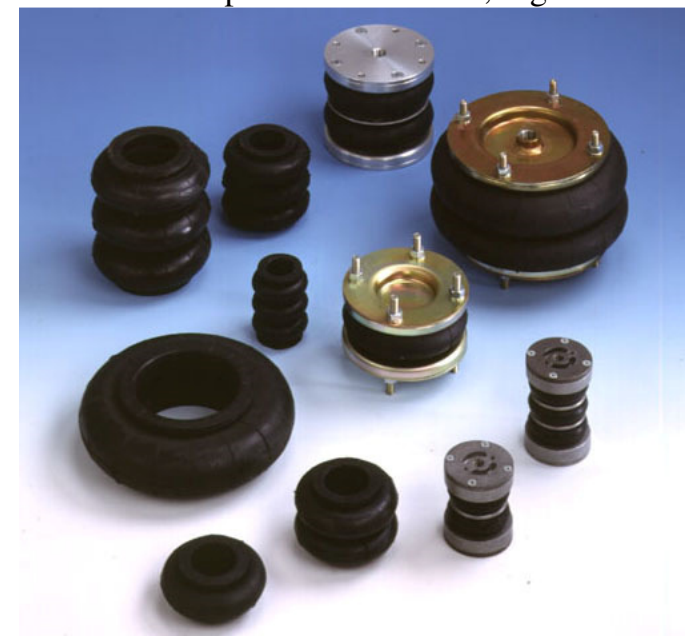

Figure 1. Different types of the flexible pneumatic elements 
These flexible elements are friction-free; they require maintenance and lubrication. They are designed for low strokes and high pressures. The height of the pneumatic element depends on diameter of the cylinder and on number of the bellows. The higher is height of the element, the larger are dimensions of the pneumatic shaft coupling in which this element is mounted. The construction provides insulation against shocks. The manufacturers also offer various types of anchoring flanges, which ensures an easy assembly of the element. The working pressure is limited by the maximum working pressure level, which is $800 \mathrm{kPa}$. Normal operational temperature is situated in the interval from $-40{ }^{\circ} \mathrm{C}$ to $70{ }^{\circ} \mathrm{C}$. For the special purposes, the manufacturer can provide another material with the working temperature in the range from $-20{ }^{\circ} \mathrm{C}$ to $115{ }^{\circ} \mathrm{C}[16]$.

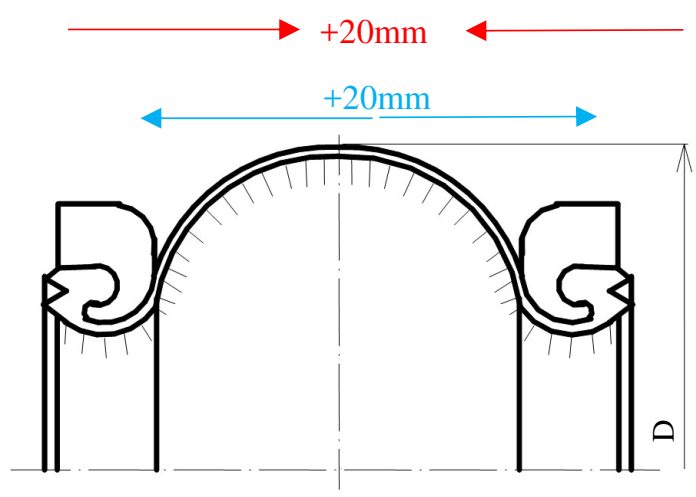

Figure 2. Investigated flexible pneumatic element PE 130/1

In order to perform the research, it was chosen the flexible pneumatic element PE $130 / 1$, whereby the marking itself defines the diameter of the cylinder $D=130 \mathrm{~mm}$ and the number of bellows, Fig. 2 .

\section{Measurement results}

The first step in the process of experimental measurements was investigation of change in the volume of the flexible pneumatic element depending on its compression and expansion.

The volume values were obtained experimentally. Based on the measured values, it is possible to define a mathematical formula, which enables to describe the volume as a function of the stroke $V=f(x)$, i.e. to define the corresponding equation, [10]:

$$
V(x)=468.6+5.436 \cdot x-0.0651 \cdot x^{2}+0.00162 \cdot x^{3} .
$$

It is evident from the measured values that the volume has changed depending on deformation of the flexible element.

When fully compressed, the value of volume was the smallest, only $373 \mathrm{~cm}^{3}$ and it gradually increased during release. In the neutral position, the volume was $460 \mathrm{~cm}^{3}$. The neutral position is such a state when the flexible pneumatic element is not pressed 
or stretched. In the case of maximum compression, the volume value was the largest and it reached $570 \mathrm{~cm}^{3}$, according to Fig. 3 .

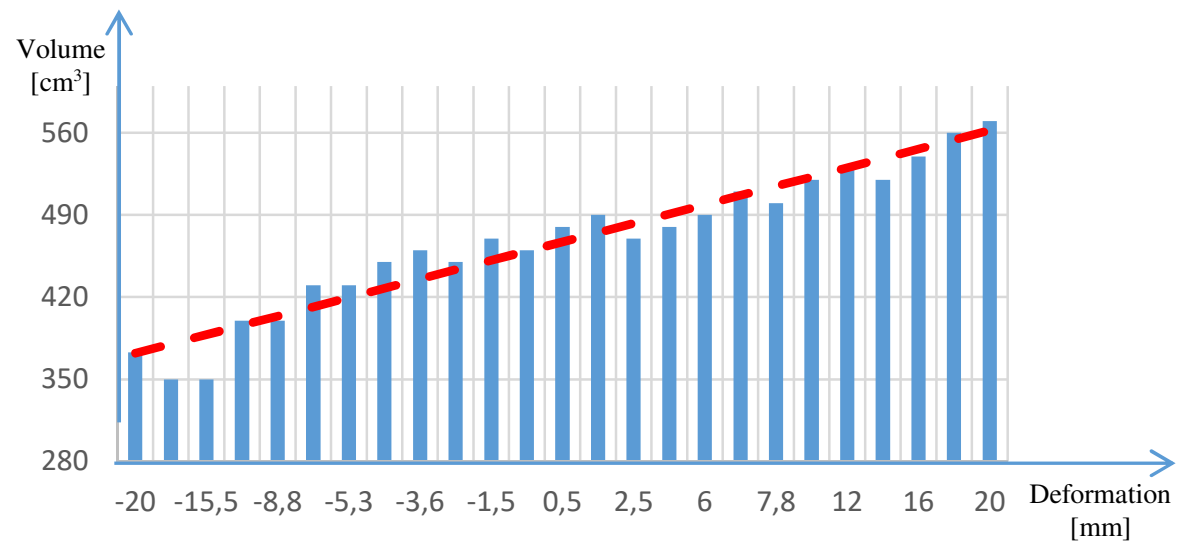

Figure 3. Dependence of volume on deformation of the pneumatic element PE 130/1

The volume of the elastic element changes during compression and expansion of this element. The values of forces, which are required for compression and expansion of the flexible element, were obtained experimentally using the digital dynamometer Sauter FK (Fig.4) with the maximum possible force F $=1000 \mathrm{~N}$ and with the accuracy $0.5 \mathrm{~N}$. The investigated flexible pneumatic element PE130/1 was inserted into this measuring device and in this way there were obtained the measured force values $\mathrm{F}$ and after then summarized in Table 1.
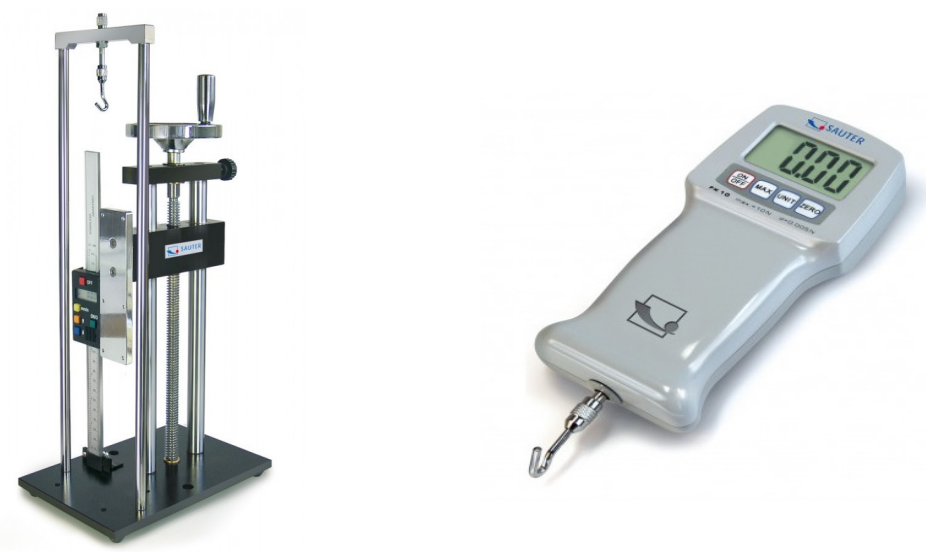

Figure 4. Digital dynamometer Sauter FK 1000 with measuring apparatuses (Photo - own sources)

The measured values of the forces were recorded using the Excel software and transformed into the form of graph in Fig. 5, which describes a dependence of the forces $\mathrm{F}$ on deformation $\mathrm{x}$ of the flexible element. Consequently, the applied software calculated and created a functionality (dependence), which is based on the measured 
force values. This dependence is described by means of the values $\mathrm{x}$ (in $\mathrm{mm}$ ) of the flexible element deformation, whereby this functionality was generated automatically using the above-mentioned software.

Table 1. The values offorces depending on deformation

\begin{tabular}{|c|c|c|c|}
\hline $\mathrm{x}[\mathrm{mm}]$ & $F[\mathrm{~N}]$ & $\mathrm{x}[\mathrm{mm}]$ & $F[\mathrm{~N}]$ \\
\hline-19 & 400 & 1 & -32 \\
\hline-18 & 370 & 2 & -48 \\
\hline-17 & 341 & 3 & -68 \\
\hline-16 & 316 & 4 & -84 \\
\hline-15 & 290 & 5 & -100 \\
\hline-14 & 268 & 6 & -116 \\
\hline-13 & 246 & 7 & -132 \\
\hline-12 & 225 & 8 & -149 \\
\hline-11 & 204 & 9 & -167 \\
\hline-10 & 186 & 10 & -186 \\
\hline-9 & 167 & 11 & -204 \\
\hline-8 & 149 & 12 & -225 \\
\hline-7 & 132 & 13 & -246 \\
\hline-6 & 116 & 14 & -268 \\
\hline-5 & 100 & 15 & -290 \\
\hline-4 & 84 & 16 & -316 \\
\hline-3 & 68 & 17 & -341 \\
\hline-2 & 48 & 18 & -370 \\
\hline-1 & 32 & 19 & -400 \\
\hline
\end{tabular}

The following Fig.5 illustrates the dependence of the measured force values on the flexible element deformation and it also shows the generated functionality $\mathrm{F}(\mathrm{x})$.

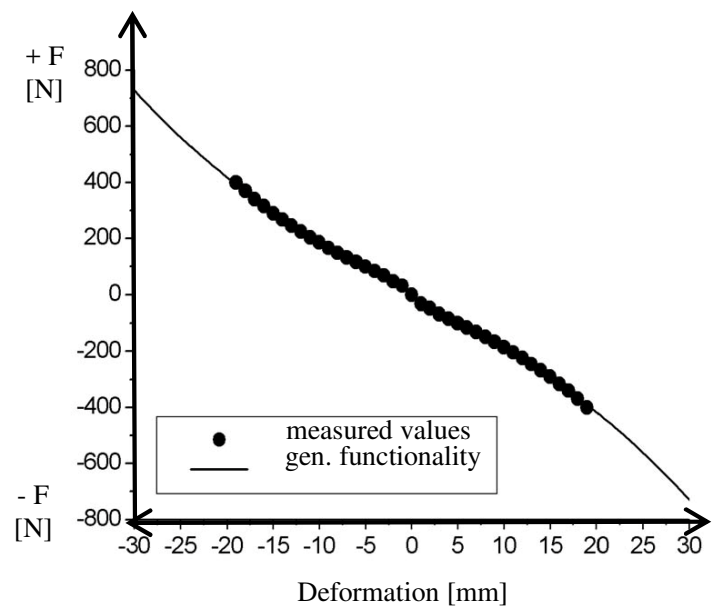

Figure 5. Dependence of the measured force values on deformation, together with the generated functionality for the flexible pneumatic element PE 130/1 
The generated functionality is described by a function $\mathrm{F}(\mathrm{x})$ where the stroke value $\mathrm{x}$ is given in millimetres.

$$
F(x)=-18.153 \cdot x-0.00686 \cdot x^{3} .
$$

This calculation allows to determine the amount of deformation energy $E_{D}$ in the pneumatic-elastic element for various deformation degree of the given flexible element. The exact definition of the deformation energy sounds: it is a such work, which has to be done in order to get the flexible body from a reference level of energy (i.e. from the "zero-level") to the new determined level.

$$
E_{D}(x)=-\int_{0}^{x} F\left(x^{\prime}\right) \mathrm{d} x^{\prime} .
$$

The calculated values of the deformation energy are visible on Fig. 6.

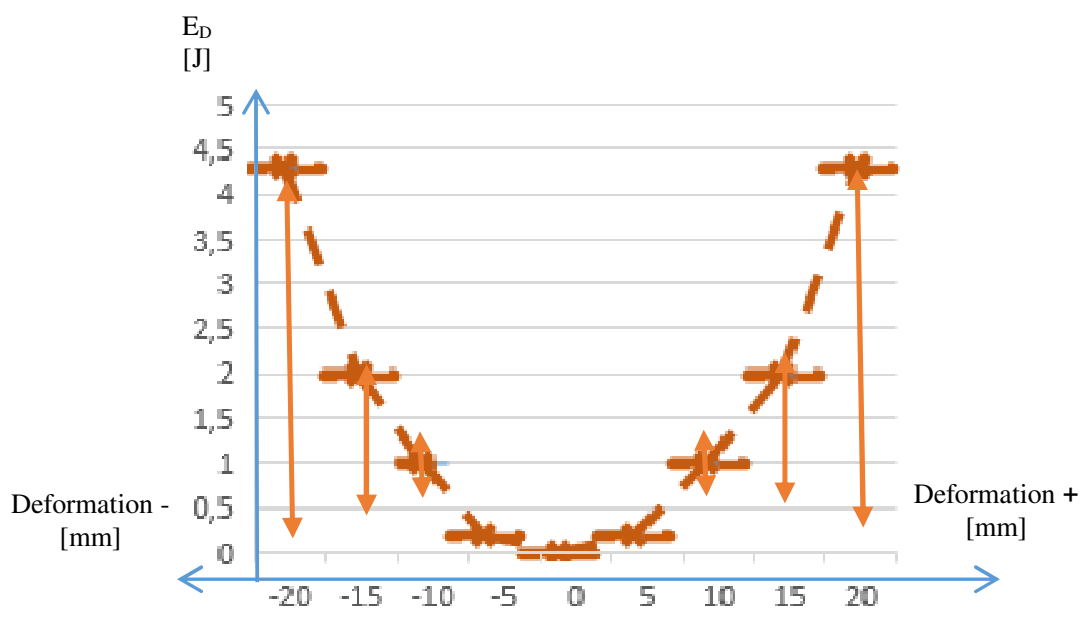

Figure 6. Dependence of deformation energy on deformation of the elastic element PE 130/1

Fig. 5 illustrates an increase of the force, which is required in order to compress or to expand the flexible element. The force gradually rises from the zero level to $400 \mathrm{~N}$ at maximum deformation of the elastic element. If the elastic element is compressed, the force is considered as positive, if it is expanded, the force goes to minus.

Fig. 6 shows that with an increasing stroke the amount of deformation energy also increases, namely up to the value $4.32 \mathrm{~J}$. When the elastic element is compressed to a maximum value of $20 \mathrm{~mm}$, the amount of deformation energy reaches the same value $4.32 \mathrm{~J}$.

It should be emphasized an important fact that the given values refer to an unpressurized open flexible rubber element. Thus, they really record only such forces and energy that are needed for deformation of the rubber. 


\section{Conclusion}

There is investigated in this article deformation of the elastic element, namely how the volume of elastic element is changing with regard to compression or expansion of it.

The subject of the performed research was a single-wave flexible element PE 130/1, which is the most often used flexible element installed in the flexible pneumatic couplings that are developed by our research team.

The volume of the elastic element changes from a minimum value at maximum compression to a maximum value at maximum expansion.

The force, which is necessary for deformation, was experimentally measured by means of the digital dynamometer. The value of force required for compression and expansion of the flexible pneumatic element was changing proportionally to the volume changes.

It is evident, from the Fig. 6 that the course of deformation energy, which is needed for compression or expansion of the pneumatic element, is non-linear; concretely this course is exponential. When the elastic element is compressed or expanded, it heats up itself and generates heat energy. Finding the amount of deformation energy is necessary for numerical solution of the heat conduction equation. The released heat energy is heating the rubber from which the elastic element is made in the whole volume and thus increases its temperature.

The article was elaborated in the framework of the Grant Projects: VEGA 1/0528/20, KEGA 006TUKE-4/2020.

\section{LITERATURA}

1. ŽULOVÁ L. GREGA R. KRAJŇÁK J., FEDORKO G., MOLNÁR V.: Optimization of noisiness of mechanical system by using a pneumatic tuner during a failure of piston machine, In: Engineering Failure Analysis. Vol. 2017, no. 79(2017), p. 845-851. - ISSN 1350-6307, 2017.

2. HOMIŠIN J.: Nové typy pružných hriadel'ových spojok: vývoj, výskum, aplikácia. TU, SjF, Košice 2002, ISBN 80-7099-834-2.

3. KRAJŇÁK J., GREGA R.: Analysis of external temperature in flexible element at various speed levels. Projektowanie, badania i eksploatacja Tom 1. - BielskoBiała: Akademia Techniczno-Humanistyczna w Bielsku-Białej s. 191-198 - ISBN 978-83-65182-93-7, 2018.

4. SRIRING M., NIMPAIBOON A., KUMARN S., SIRISINHA Ch., TOKI S.: Viscoelastic and mechanical properties of large and small particle natural rubber before and after vulcanization, Polymer Testing, Volume 70, Pages 127-134, September 2018.

5. URBANSKÝ M., KAŠŠAY P., PUŠKÁR M.: Drum pneumatic flexible shaft coupling applicable in the automotive industry. Projektowanie, badania i 
eksploatacja 2020. - Bielsko: Wydawnictwo naukowe Akademii technicznohumanistycznej w Bielsku-Białej s. 363-370. ISBN 978-83-66249-54-7, 2020.

6. JAKUBOVIČOVÁ L., SÁGA M., KOPAS P., HANDRIK M., VAŠKO M.: Some Notes on Analysis of Bending and Torsion Combined Loading, Machine Dynamics Research 34 (3): 97-105. ISSN 2080-9948, 2010.

7. GREGA R., KRAJŇÁK J., ŽUL'OVÁ L., FEDORKO G., MOLNÁR V.: Failure analysis of driveshaft of truck body caused by vibrations, In: Engineering Failure Analysis. Vol. 79, p. 208-215. - ISSN 1350-6307, 2017.

8. URBANSKÝ M., HOMIŠIN J.: Principle of torsional vibration control on mechanical system at inner accidental event occurrence, In: Projekt interdyscyplinarny projektem 21. wieku. - Bielsko-Biała : Wydawnictwo Naukowe ATH, 2017 P. 333-340. - ISBN 978-83-65192-80-7, 2017.

9. PUŠKÁR M., FABIAN M., KÁDÁROVÁ J. BLIŠŤAN P., KOPAS M.: Autonomous vehicle with internal combustion drive based on the homogeneous charge compression ignition technology, In: International Journal of Advanced Robotic Systems. Vol. 14, no. 5, p. 1-8. - ISSN 1729-8814, 2017.

10. KRAJŇÁK J., HOMIŠIN J., GREGA R., KAŠŠAY P., URBANSKÝ M.: The failures of flexible couplings due to self-heating by torsional vibrations validation on the heat generation in pneumatic flexible tuner of torsional vibrations, Engineering Failure Analysis. - Amsterdam: Elsevier č. 119, s. 1-13. ISSN 1350-6307, 2021.

11. JAKUBOVIČOVÁ L., ZAVADINKA P., JAKUBOVIČ J.: Transport duty cycle measurement of hybrid drive unit for mixing drum, Adv. Intell. Syst. Comput. 393, 219-224, 2015.

12. HARACHOVÁ, D.: Decomposition of driving systems specified for rehabilitation machines, In: Ad Alta: Journal of Interdisciplinary Research. Vol. 7, no. 2 (2017), p. 271-273. - ISSN 1804-7890, 2017.

13. HOMIŠIN J., KAŠŠAY P., PUŠKÁR M., GREGA R., KRAJŇÁK J., URBANSKÝ M., MORAVIČ M.: Continuous tuning of ship propulsion system by means of pneumatic tuner of torsional oscillation, International Journal of Maritime Engineering: Transactions of The Royal Institution of Naval Architects. Vol. 158, no. Part A3, p. A231-A238. - ISSN 1479-8751, 2016.

14. FALTINOVÁ E., KULKA J., MANTIČ M., KOPAS M., GREGA R.: Určovanie dynamickej stability mobilných pracovných strojov vo vertikálnej rovine, Magazín stroje - technológie - ekológia. - Bratislava: M.I.A. Roč. 14, č. 2, s. 20 22, ISSN 2453-7500, 2019.

15. GREGA R., KRAJŇÁK J., HOMIŠIN J., KOPAS M., SÁGA M., JAKUBOVIČOVÁ L.: Znižovanie hlučnosti piestového kompresora pri deaktivácii valca, Technológ. Žilina: Žilinská univerzita v Žiline, 2009 Roč. 11, č. 3, s. 33-38. - ISSN 1337-8996, 2019.

16. Catalog: Norgren Herion, 2020. 